\title{
Author Correction: mRNA vaccines for infectious diseases: principles, delivery and clinical translation
}

Namit Chaudhary (D), Drew Weissman and Kathryn A. Whitehead (D)

Correction to: Nature Reviews Drug Discovery https://doi.org/10.1038/s41573-021-00283-5, published online 25 August 2021.

The chemical structure of the $5^{\prime}$ cap of in vitro-transcribed mRNA in Figure 1a has been revised to show the correct stereoisomer of 7-methylguanosine.

https://doi.org/10.1038/s41573-021-00321-2 I Published online 21 September 2021

(๑) Springer Nature Limited 2021

\section{Publisher Correction: Evolution of the market for mRNA technology}

Wen Xie, Baiping Chen and John Wong

Correction to: Nature Reviews Drug Discovery https://doi.org/10.1038/d41573-021-00147-y, published online 2 September 2021

The colour of the bar for mRNA therapeutics in phase Il trials in Figure $1 \mathrm{~b}$ was incorrect. This has now been corrected in the online versions.

https://doi.org/10.1038/s41573-021-00326-x I Published online 4 October 2021

๑) Springer Nature Limited 2021 